\title{
Methods and Proposals for Meeting Energy Needs
}

\author{
Wes Grebski \\ The Pennsylvania State University, USA \\ Stefan Czerwiński \\ Jan Kania \\ Silesian University of Technology, Poland
}

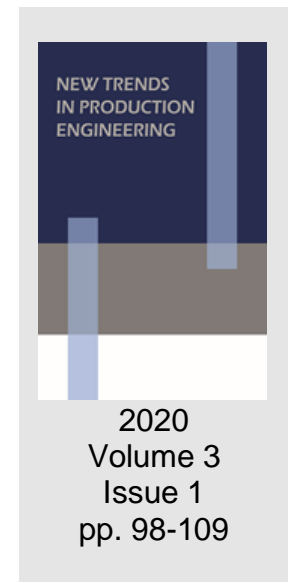

Date of submission to the Editor: 02/2020

Date of acceptance by the Editor: 03/2020

\section{INTRODUCTION}

The target audience of this research is technical personnel as well as policy makers in the power generation industry. The authors hope that the article will stimulate discussion and help with the development of a well-balanced solution. The development of the economy and urbanization causes an increased demand for electricity. Simultaneously new technologies used in construction and transportation are becoming more energy efficient (Mazzola et al., 2019; Nocera et al, 2019; Von Knorring, 2019). Electricity consumption in the United States has remained consistent over the past 15 years (Table 1).

Table 1 Electricity consumption in Poland and the USA

\begin{tabular}{|c|c|c|}
\hline Year & $\begin{array}{c}\text { Electric energy usage } \\
\text { in the USA } \\
\text { [billions of } \mathbf{k W} \text { ] }\end{array}$ & $\begin{array}{c}\text { Electric energy usage } \\
\text { in Poland } \\
\text { [billions of } \mathbf{k W h} \text { ] }\end{array}$ \\
\hline 1975 & 1747 & 105.3 \\
\hline 1980 & 2094 & 121.8 \\
\hline 1985 & 2324 & 128.3 \\
\hline 1990 & 2837 & 128.0 \\
\hline 1995 & 3164 & 122.8 \\
\hline 2000 & 3592 & 132.2 \\
\hline 2005 & 3811 & 139.6 \\
\hline 2010 & 3886 & 144.4 \\
\hline 2011 & 3883 & 147.7 \\
\hline 2012 & 3832 & 148.4 \\
\hline 2013 & 3868 & 149.8 \\
\hline 2014 & 3903 & 151.0 \\
\hline 2015 & 3900 & 154.1 \\
\hline 2016 & 3902 & 159.1 \\
\hline 2017 & 3864 & 162.8 \\
\hline 2018 & 3946 & 166.8 \\
\hline
\end{tabular}

Source: Authors' own study based on Wang (2019).

The development of the economy, industry and urban agglomerations is balanced by an increase in energy efficiency (Federal Energy Regulatory, 2019; 
Energy Information Administration, 2020; Wang, 2019). There were even periods of decline in electricity consumption (between 2010-2012). This was a period of great progress in increasing the energy efficiency of equipment, appliances, motor vehicles, production processes as required by the federal government of President Barak Obama. In Poland, electricity consumption is constantly increasing except for 1995 , where there was a small decrease in consumption caused by the economy converting to market driven economy.

\section{ALTERNATIVE METHODS FOR SOLVING THE ENERGY PROBLEM}

Meeting the demand of society and the economy for electricity can be obtained by two methods:

- increasing electricity production,

- increasing energy efficiency.

Both methods can be used simultaneously.

\section{Reducing Demand by Increasing Energy Efficiency}

Scientific research into increasing energy efficiency began in the United States (USA) in 1973, when the Organization of the Petroleum Exporting Countries (OPEC) imposed an embargo on oil exports. This resulted in a sharp increase in the prices of all types of fuels (Nadel, 2015; Energy star...). In 1980, the American Council for an Energy Efficient Economy (ACEEE) was established in the USA. ACEEE is a government commission set up to develop a strategy to reduce energy consumption in the USA. The mission of the ACEEE was to make the USA economy independent of the policies of OPEC countries. Over the past 40 years there has been great progress in reducing the energy intensity of the USA economy. The energy intensity of the economy was measured using the energy demand indicator for one dollar of Gross Domestic Product (GDP). National energy consumption during the year is divided by GDP. The energy demand index has decreased in the USA from $13.8 \mathrm{MJ} /$ dollar in 1980 to 6.7 $\mathrm{MJ} /$ dollar in 2014 . This represents a $50 \%$ reduction in the energy demand ratio. The reduction in energy demand resulted in savings of $\$$ billion (USD) on a national scale. The savings associated with the reduction of energy consumption per capita in 2014 amounted to $\$ 2,500$ (USD). Research on increasing energy efficiency has created a lot of new jobs and boosted the economy. The reduction of energy consumption and national standards related to energy efficiency resulted in a decrease in demand for oil imports. The demand for oil imports in 2014 dropped to $44 \%$ of consumption from the 1970s. The reduction in the consumption of liquid fuels and natural gas has reduced the emissions of carbon dioxide, sulfur dioxide, mercury and other harmful substances that contribute to increasing environmental pollution. In 2014, carbon dioxide emissions in the USA amounted to 5,404 million tons, a 10\% reduction as compared to 2005 . The effect of reducing the energy consumption was obtained by increasing the energy efficiency of machinery and equipment, buildings, vehicles, aircraft, etc. The energy consumption of production processes was also reduced. Strict standards have been introduced for the energy efficiency of household 
appliances as well as heating and air conditioning systems (Center for Climate..., 2019; American Council for... 2019a; American Council for..., 2019b; Energy Efficiency Resource...; Energy Efficiency Legislative..., 2019). Energy Efficiency (1986) and Energy Star labels (1992) had been introduced. The federal government and state governments provide tax breaks to companies that manufacture or install energy-saving devices. Tax breaks are also offered to private individuals for installations aimed at increasing energy efficiency and reducing the consumption of all types of energy. Much has already been done and a plan was developed to extend current initiatives until 2050. The plan for the next 30 years is ambitious and aims to further reduce energy consumption by $40-60 \%$ compared to current consumption (Nadel, 2015; Energy star...; Kamahina et al, 2019)

The plan to reduce energy consumption by 2050 focuses on the following:

- $\quad$ using computers to monitor and control energy consumption,

- improving the energy efficiency of computers, televisions, freight and passenger lifts,

- evolving residential and commercial buildings towards 'passive selfsufficient buildings' in terms of energy demand,

- improving energy consumption in production processes,

- developing electric and hybrid self-driving motor vehicles,

- modernizing existing buildings in terms of significantly reducing energy consumption,

- increasing the efficiency of electrical networks,

- reducing losses of energy transmission and distribution through the implementation of "Heat and Power" systems (local energy generation systems),

- developing new energy-efficient housing and transport systems,

- $\quad$ raising public awareness of the need for economical energy management,

- $\quad$ introducing a tax policy rewarding energy saving.

The plan until 2050 is focused on the development of an economy based on energy saving and environmental protection for future generations (Nadel, 2015; Energy star...).

There are also many state initiatives and programs to reduce energy consumption. Examples of such programs in the state of Pennsylvania are as follows:

- low-interest loans (1\%) from \$ 1000 to \$10,000 (USD) for installation of economical heating and air conditioning systems,

- discounts on the purchase of high-energy refrigerators, water heaters, washing machines, dryers, kitchen stoves, etc.,

- tax rebates on the installation of PVW systems in single-family homes or commercial buildings. In 2020 , the tax rebate amounts to $26 \%$ of the investment cost (Consumer Reports...).

Energy companies are obliged to purchase privately generated electricity (at the same prices as the ones they collect for the supplied electricity): 
- tax rebates for the purchase of an electric or hybrid car with a battery capacity of at least $5 \mathrm{kWh}$,

- the ability to purchase electricity from various suppliers. Charges for electricity and transmission of electricity are collected separately. The customer cannot choose the company that distributes energy, but has the option of choosing a company that generates electricity.

Pennsylvania low-income residents ( $\$ 24,980$ gross per year for one person, $\$$ 33,820 for a 2 -person family and $\$ 42,660$ for a 3-person family) can benefit from free thermal insulation programs to reduce energy consumption for the home in which they live.

\section{Increase in Energy Production}

The increase in electricity production is always a more costly initiative compared to the costs of increasing the energy efficiency of appliances. The increase in energy efficiency can be accomplished with less financial expenditure (especially some basic initiatives). The increase in electricity production should be preceded by a detailed analysis of needs (energy audit) which is available in all geographical regions.

\section{COST OF GENERATING ELECTRICITY FROM VARIOUS SOURCES}

A comparison of the costs of generating electricity (in USA) from various sources, broken down into maintenance, repair and maintenance, and fuel costs is shown in Table 2.

Table 2 Costs of generating electricity generated from various sources

\begin{tabular}{|c|c|c|c|c|c|c|c|c|c|c|c|c|c|c|c|c|}
\hline \multirow[t]{2}{*}{ Year } & \multicolumn{3}{|c|}{ Coal } & \multicolumn{5}{|c|}{ Nuclear } & \multicolumn{3}{|c|}{ Hydro } & \multicolumn{3}{|c|}{ Gas } & \multicolumn{2}{|c|}{ Terbine } \\
\hline & O & $\mathbf{N}$ & $\mathbf{P}$ & C & 0 & $\mathbf{N}$ & $\mathbf{P}$ & C & O & $\mathbf{N}$ & $\mathbf{P}$ & C & 0 & $\mathbf{N}$ & $\mathbf{P}$ & C \\
\hline 2008 & 0.37 & 0.36 & 2.84 & 3.58 & 0.99 & 0.62 & 0.53 & 2.18 & 0.58 & 0.39 & 0 & 0.97 & 0.38 & 0.27 & 6.42 & 7.08 \\
\hline 2009 & 0.42 & 0.39 & 3.23 & 4.05 & 1.00 & 0.63 & 0.53 & 2.17 & 0.49 & 0.35 & 0 & 0.84 & 0.31 & 0.25 & 5.19 & 5.75 \\
\hline 2010 & 0.40 & 0.40 & 2.77 & 3.52 & 1.05 & 0.68 & 0.67 & 2.40 & 0.53 & 0.38 & 0 & 0.92 & 0.28 & 0.27 & 4.32 & 4.87 \\
\hline 2011 & 0.40 & 0.40 & 2.71 & 3.51 & 1.09 & 0.68 & 0.70 & 2.47 & 0.51 & 0.37 & 0 & 0.89 & 0.28 & 0.29 & 3.88 & 4.45 \\
\hline 2012 & 0.44 & 0.45 & 284 & 3.72 & 1.25 & 0.73 & 0.76 & 2.74 & 0.67 & 0.46 & 0 & 1.13 & 0.25 & 0.27 & 3.05 & 3.56 \\
\hline 2013 & 0.46 & 0.44 & 2.89 & 3.79 & 1.25 & 0.66 & 0.81 & 2.73 & 0.66 & 0.43 & 0 & 1.09 & 0.26 & 0.28 & 3.26 & 3.79 \\
\hline 2014 & 0.46 & 0.51 & 2.94 & 3.90 & 1.24 & 0.67 & 0.77 & 2.68 & 0.73 & 0.46 & 0 & 1.19 & 0.26 & 0.29 & 3.71 & 4.26 \\
\hline 2015 & 0.52 & 0.54 & 2.67 & 3.73 & 1.12 & 0.71 & 0.75 & 2.57 & 0.84 & 0.51 & 0 & 1.34 & 0.23 & 0.26 & 2.82 & 3.32 \\
\hline 2016 & 0.51 & 0.55 & 2.55 & 3.61 & 1.09 & 0.70 & 0.75 & 2.54 & 0.67 & 0.43 & 0 & 1.09 & 0.25 & 0.27 & 2.49 & 3.01 \\
\hline 2017 & 0.50 & 0.51 & 2.53 & 3.54 & 1.03 & 0.66 & 0.75 & 2.44 & 0.63 & 0.39 & 0 & 1.03 & 0.25 & 0.28 & 2.65 & 3.17 \\
\hline 2018 & 0.52 & 0.53 & 2.54 & 3.59 & 1.18 & 0.59 & 0.71 & 2.39 & 0.67 & 0.40 & 0 & 1.07 & 0.24 & 0.27 & 2.74 & 3.24 \\
\hline
\end{tabular}

Source: Own study based on Federal Energy Regulation Commission (2019).

$\mathrm{O}$ - Maintenance, $\mathrm{N}$ - Repair and maintenance, P - Fuel, C - Total energy cost

Data from Table 2. are presented in graphical form on the charts (Figure 1-4). The drawings show graphically the impact on the price of kWh of energy by the basic components of energy generation process, such as maintenance, repairs and maintenance, fuel cost and total cost of generation. 


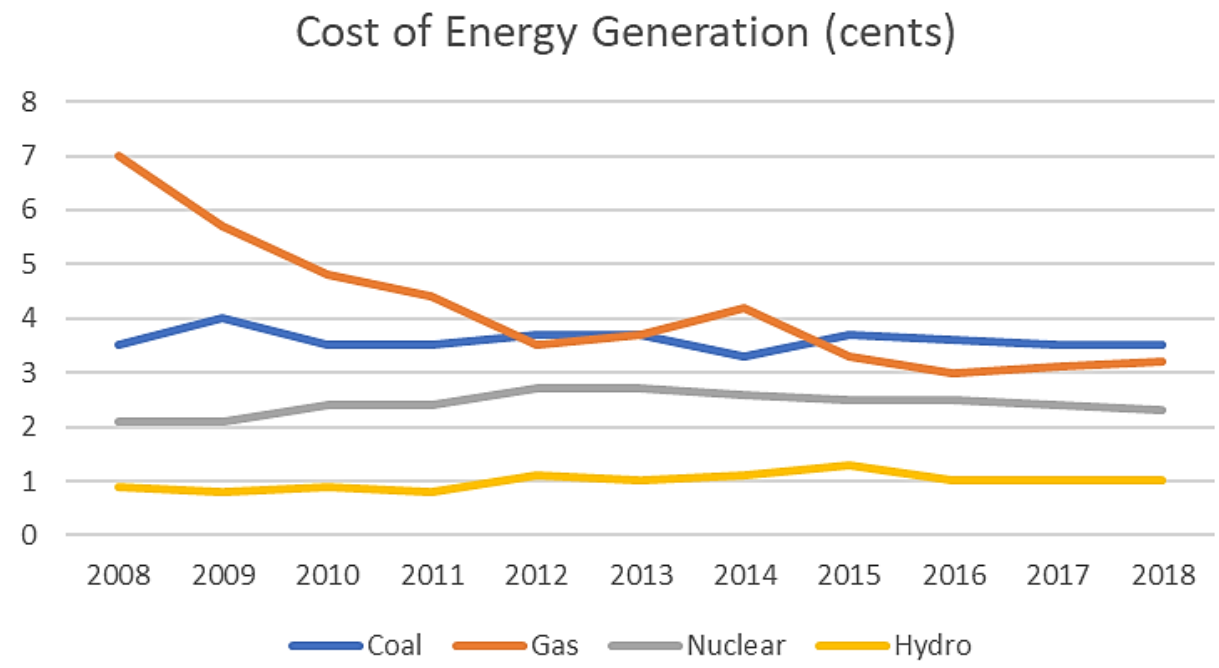

Fig. 1 Total cost of generating electricity from various source in cents (USD) per kWh

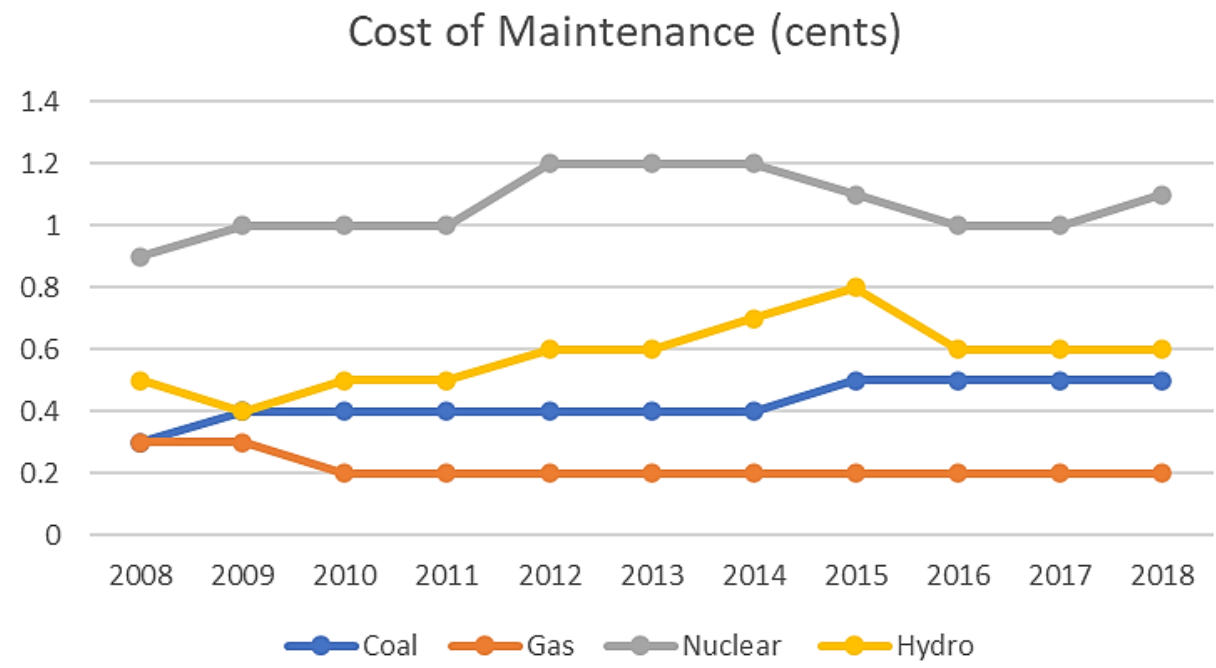

Fig. 2 Average cost of maintaining traffic in power plants generating electricity from various sources in cents (USD) per $\mathrm{kWh}$

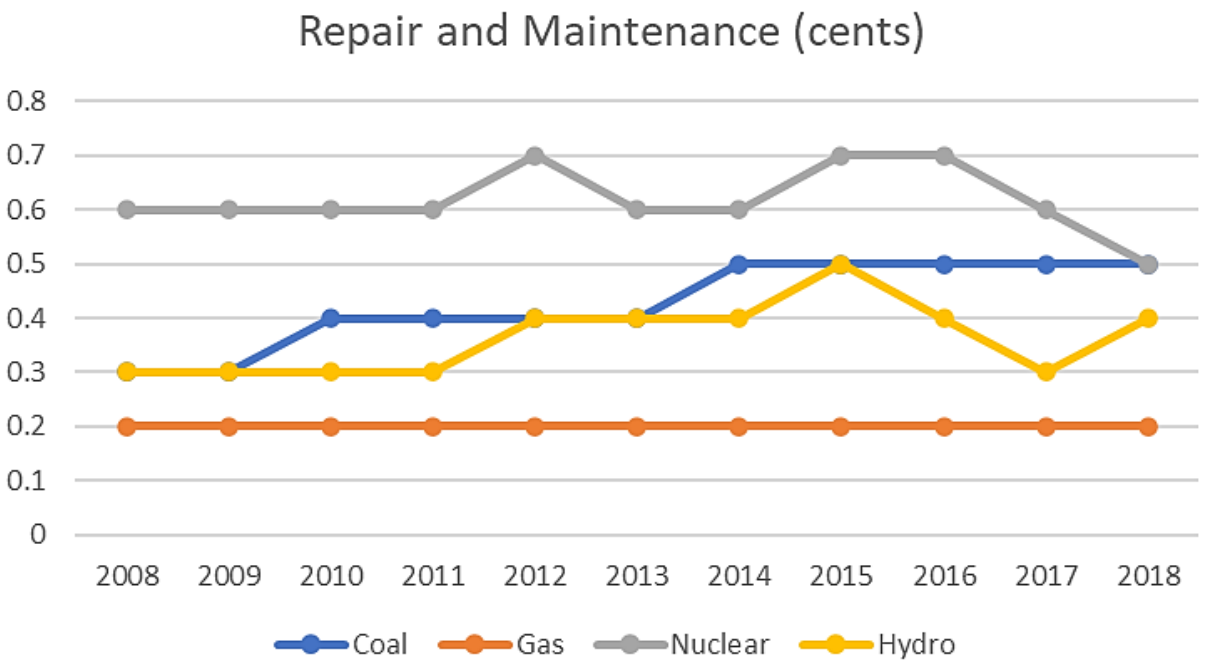

Fig. 3 Average cost of repairs and maintenance in power plants generating electricity (from various sources in cents (USD) per kWh) 
Fuel Cost (cents)

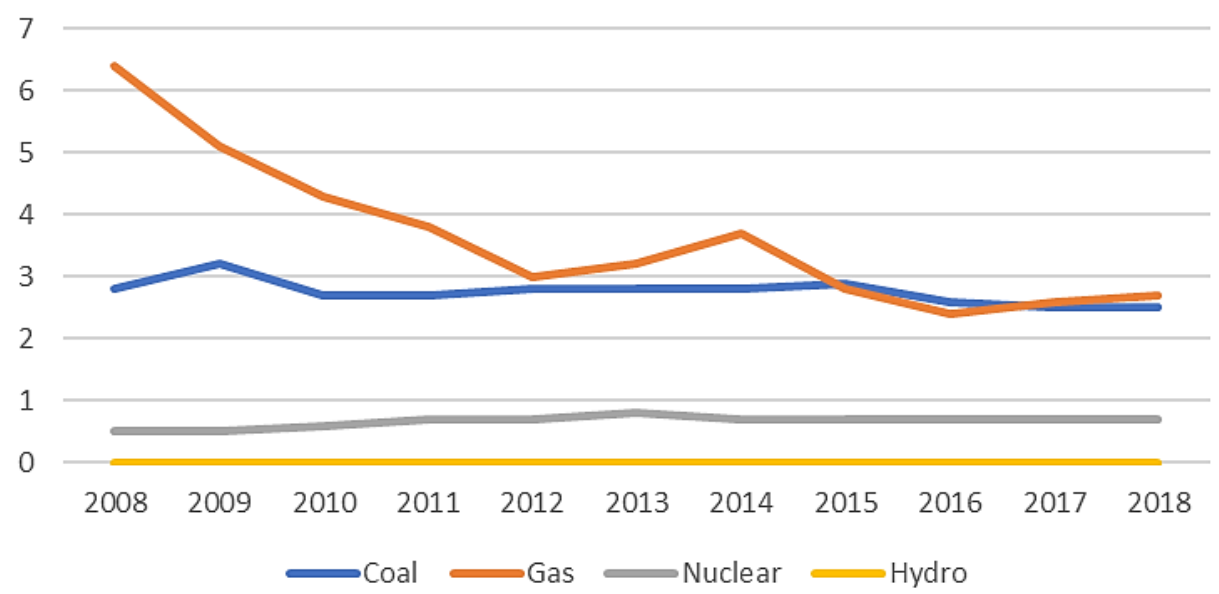

Fig. 4 Average cost of fuel used in power plants generating electricity from various sources in cents (USD) per kWh

Table 3 shows the diversification of electricity generation, including construction costs and participation in the national energy mix.

Table 3 Diversification of electricity acquisition

\begin{tabular}{|l|c|c|}
\hline $\begin{array}{c}\text { Power plant type } \\
\text { (by fuel type) }\end{array}$ & $\begin{array}{c}\text { Construction } \\
\text { cost } \mathbf{\$} \mathbf{k W}\end{array}$ & $\begin{array}{c}\text { \% share } \\
\text { in the national energy mix }\end{array}$ \\
\hline Nuclear power plants & $5500-8100$ & 19.7 \\
\hline Coal power plants & $3000-3500$ & 30.4 \\
\hline Natural gas power stations & $1000-2000$ & 33.8 \\
\hline Hydroelectric power stations & $1000-2300$ & 6.5 \\
\hline Wind farms & $1600-2000$ & 5.5 \\
\hline Solar power plants (PV systems) & $3000-3500$ & 2 \\
\hline
\end{tabular}

Source: (The Outsider Club...; Kaufman, 2019; U.S. Energy Information..., 2017).

\section{Cost of Electricity Generated from Hard Coal (anthracite coal)}

The cost of electricity from hard coal and natural gas remains high in the USA. In 2018, the cost from these sources was about \$ 0.035 (USD/kWh). The cost of purchasing coal and gas for electricity production in 2018 were $\$ 0.025$ (USD/kWh) for coal and \$ 0.027 (USD/kWh) for natural gas. Maintenance and repair costs for electricity generation from coal and gas were small and in 2018 amounted to a total of about $\$ 0.015$ (USD/kWh). In the USA, 30.4\% of electricity is produced from coal and $33.8 \%$ from natural gas $(64.2 \%$ in total). These are well-tried technologies with low complexity (The Outsider Club...; Kaufman, 2019). Residues from coal combustion can be recovered and used to produce hollow blocks and other construction components. Very often, however, combustion products are used to harden the construction site (United States Environmental...).

\section{Cost of Electricity Generated from Nuclear Energy}

The lowest cost of electricity is generated by nuclear power plants. In 2018, the cost was about $\$ 0.024$ (USD/kWh). The cost of uranium fuel was also low (at around $\$ 0.0075 \mathrm{USD} / \mathrm{kWh})$. On the other hand, maintenance and repair costs were higher compared to coal-fired power plants and reached $\$ 0.016$ 
(USD/kWh) in 2018. In total, the cost of electricity generated in nuclear power plants was $31 \%$ lower than the cost of electricity generated from fossil fuels (coal). In the USA, $19.7 \%$ of the electricity used in the country comes from nuclear power plants (Asaff, 2020; Office of Nuclear Energy, 2020) There are currently 61 nuclear power plants in the USA with a capacity range from 582 MW (one reactor) to a capacity of $3937 \mathrm{MW}$ (three reactors).

\section{Cost of Electricity Generated from Renewable Sources}

The cost of electricity from traditional hydropower plants was the cheapest at \$ 0.01065 (USD/kWh) in 2018. Of course, this is only the cost of maintenance and repairs. Hydroelectric power plants only produce $6.5 \%$ of electricity generated in the USA. Hydroelectric power plants require a large financial outlay and can be built in only a few locations with favorable natural conditions. There are very few new hydropower plant projects.

The cost of electricity generated from other renewable energy sources, such as wind farms, photovoltaic (PV) systems and biomass is in the range of $\$ 0.10$ to $\$ 0.13$ (USD/kWh). In the USA, about $5.5 \%$ of the energy consumed comes from wind farms, $1.5 \%$ from biomass and about $2 \%$ from PV systems. Electricity generated from renewable energy sources is about 2.8 times more expensive than electricity produced from coal and about 4.2 times more expensive than energy generated in nuclear power plants. (Based on the authors' own calculations assuming the average cost of energy from renewable sources is $\$$ $0.10(\mathrm{USD} / \mathrm{kWh})$, the cost of energy from coal is $\$ 0.035(\mathrm{USD} / \mathrm{kWh})$, and the cost of energy from nuclear power plants is $\$ 0.024$ (USD/kWh).

\section{OPPORTUNITIES AND THREATS IN GENERATING ELECTRICITY FROM DIFFERENT SOURCES}

\section{Opportunities and Threats When Generating Energy from Hard Coal (anthracite coal)}

Coal-fired power plants are proportionally inexpensive to build because they use popular and proven electricity generation technology. Hard coal and lignite are still the cheapest source of energy proportionally. Hard coal and lignite are used to produce $30.4 \%$ of electricity in the USA. In some countries (The Outsider Club...; Kaufman, 2019), the share of coal in the generation of electricity is much higher (80\% in China, $44 \%$ in India and $35 \%$ in England).

Coal is a popular fuel in the USA because of the existing mining and transport infrastructure. However, this infrastructure is becoming more and more outdated. Coal mining in the USA is high and ranks second in the world after China. In 2018, coal mining in the USA reached 687 million tons (U.S. Energy Information..., 2020). Energy from coal competes with nuclear energy, which is considered dangerous especially after the Fukushima power plant disaster in Japan. However, alternative renewable energy sources such as solar and wind energy are still much more expensive (Trabish, 2014). Coal is a relatively dirty fuel. When burning coal in power plants, about $100 \mathrm{~kg}$ of carbon dioxide is released into the atmosphere to generate $3000 \mathrm{kWh}$ of electricity. (By 
comparison, $71.4 \mathrm{~kg}$ are released when burning gasoline and $53 \mathrm{~kg}$ are released when burning natural gas.) In addition, when burning hard coal or lignite, sulfur dioxide and mercury are released into the atmosphere. In the USA, existing coal power plants are obsolete (most of them are over 40 years old) emitting $38 \%$ of the carbon dioxide generated into the USA atmosphere. The situation is even worse in many other emerging countries. China uses more coal than the USA, Europe and Japan together (The Outsider Club...; Kaufman, 2019). Sulfur dioxide discharged into the atmosphere causes acid rain and, in combination with carbon dioxide, causes lung cancer and other respiratory diseases. In 2011, 260,000 people in China died of air pollution by burning coal (The Outsider Club...). Health and environmental hazards are the weaknesses of coal-fired power plants.

In the USA, carbon dioxide emission standards are constantly decreasing, and therefore the share of coal-fired power plants in electricity production is decreasing. (In the USA, electricity production from coal power plants accounted for $57 \%$ in $1985,42 \%$ in 2011 and $30.4 \%$ at present). Environmental standards in the USA will restrict the carbon dioxide emissions to $30 \%$ over the next 15 years. This is not just a problem in the USA. The European Union (EU) countries and China are moving in the same direction. China limits carbon dioxide emissions, especially around Beijing and other large urban agglomerations. For a long time, since 1993, research is being carried out on the implementation of clean coal technologies that relate to all elements of the coal mining, transport, storage and combustion processes. Clean coal technologies is about eliminating harmful sulfur dioxide as well as nitrogen oxides. One of the easiest methods is to wash the shredded coal before burning to remove unwanted minerals. Electrostatic filters remove particles that cause respiratory diseases.

When it comes to carbon emissions, research is being carried out to capture and store liquid carbon dioxide in deep water (500-3000 meters). The carbon storage method is still at the research stage and has many opponents fearing environmental pollution.

Cleaner energy sources like natural shale gas extracted by fracking have become relatively cheap. The use of shale gas for electricity generation is increasing. Currently, the share of natural gas used to generate electricity in the USA is at the level of $33.8 \%$. China is also moving towards natural gas, but it only occurs in certain areas of the country. China is developing electricity production from hydroelectric plants as well as solar and wind systems. Solar and wind systems are becoming more and more popular in the USA and are now becoming less expensive. Over time, coal-fired power plants will be eliminated due to environmental hazards.

\section{Opportunities and Threats in Generating Energy from Nuclear Sources}

Nuclear energy is always a very controversial topic because it has many supporters and opponents. Generating electricity in nuclear power plants is the cheapest and most reliable and is not combined with the release of carbon dioxide and other harmful gases. Uranium is not an expensive fuel source (One 
grain of uranium produces as much energy as one ton of coal or 600 liters of crude oil), Uranium is cheaper to transport. The atomic reactor can operate without refilling uranium fuel for 1-2 years (the record period is 940 days). Nuclear power plants do not require continuous fuel delivery compared to coalfired power plants, they are not dependent on weather conditions and are reliable. (Nuclear power plants work at full power $92 \%$ of the time). Nuclear power plants are comparable to hydro or wind power plants because they do not generate any type of gas emissions. This is a significant advantage. In 1979, Pennsylvanians were shaken by the melting of one reactor at Three Mile Island. A high dose of radiation threatened the health of residents. Based on this unfortunate accident, safety regulations, crew training and radiation protection have changed. The new technology of building nuclear reactors is safer. However, it is still controversial. Uranium mines and the uranium enrichment process is considered dangerous due to radiation. The removal, transport and storage of "burnt" uranium is also controversial. "Burnt" uranium is placed in water tanks (6 meters deep) to cool it for a few weeks. However, released residual nuclear reaction still occurs and associated radiation is emitted. Water in pools where 'burnt' uranium is stored is very radioactive and can cause radioactive contamination of the area. This is what happened at the Japanese Fukushima nuclear power plant. Pollution and contamination of the area caused by an accident at a nuclear power plant causes heavy metals to enter the environment combined with radiation. It can be very harmful to animal, plants and humans (Asaff, 2020; Office of Nuclear Energy, 2020).

Nuclear reactors are built with triple protection against radiation leakage. Despite this, several reactors in the USA have been shut down due to failures. They are no longer used, but still contain highly radioactive substances. Disassembly and removal of these shut down reactors is very risky and expensive. Nuclear energy is still the most controversial form of energy. The nuclear energy industry generates $\$ 60$ billion of national income and gives jobs to approximately 50,000 people. The transport of radioactive waste from a nuclear power plants to a storage site in a concrete underground warehouse in the Nevada desert is a big problem. Residents' protests the transport of radioactive waste by road transport, so radioactive waste is stored in "temporary warehouses" on the premises of nuclear power plants. This is a concern. The construction of new nuclear power plants is expensive and unpopular with the public. In the USA it is a difficult undertaking. Currently there is only one nuclear power plant under construction in Waynesboro Georgia, with completion date 2021-2022. There is talk of smaller reactors in the future. However, these projects are still at the research stage (Asaff, 2020; Office of Nuclear Energy, 2020).

\section{Opportunities and Threats in Generating Energy from Renewable Sources} In the USA (Energy Information Administration, 2020; Wang, 2019), around 16\% of electricity is currently from renewable sources (mainly wind energy $(5.5 \%)$, biomass $(1.5 \%)$, solar $(2.0 \%)$ and hydropower $(6.5 \%))$. Wind energy is used by 
commercial energy companies as well as by individual home or farm owners. Solar systems are installed mainly by owners of single-family homes as well as small and medium-sized enterprises. Tax policy favors these types of energy sources. Tax breaks reduce installation costs by around $30-50 \%$. The problem of wind or solar energy is the integration with the commercial power grid system. Large energy companies were not interested in integrating small solar systems. To change this, the government-imposed requirements on the energy industry, which is obliged to purchase electricity generated by individual consumers. This is done by using the energy grid as an energy 'storage'. During the day, solar systems generate more than the demand for energy in the household. Energy is sold to an energy company. In the evening, energy is bought back by the household. The fees are only for the net balance of energy consumption. If the generation exceeds consumption, the energy company buys excess energy. Many single-family homes are self-sufficient in energy. Excess energy can also be used to charge an electric car. There are residential developments of singlefamily houses, especially in states with high sunlight, where a huge PV system is installed for the needs of the entire development. If you own a house in such a development, you do not pay the electricity bill (heating, air conditioning, charging an electric car is free). Of course, you pay for the purchase of a share in the solar system. Prices are still relatively high (around \$ 400,000 (USD) for a single-family house connected to a district PV system), but with time they should become lower. Individual states introduce standards regarding the share of renewable energies in the generation of electricity. Energy companies receive tax rebates for integration of individual small energy producers into the energy network. Since electricity generated from renewable sources is more expensive, tax breaks are necessary to continue the development of renewable energy sources. The costs of energy generated from alternative sources are constantly falling and tax breaks can be abolished once prices have equalized (Energy Information Administration, 2020).

\section{PRACTICAL CONCLUSIONS AND RECOMMENDATIONS}

The energy problem and demand for electricity reflects the habits and traditions of society as well as the nature of the economy. The problem of energy economy cannot be solved only by increasing energy consumption. A more effective method would be a holistic method that could include the following initiatives:

- changes in building regulations to reduce energy losses and increase energy efficiency,

- analysis of energy consumption in production processes,

- changing regulations and introducing tax breaks for people who generate electricity (solar or wind) for their use and for sale,

- introduction of tax breaks for companies that generate electricity from renewable sources for their own use and for sale,

- building in the particularly polluted and highly urbanized region one demonstrative passive housing development completely self-sufficient in terms of energy demand, 
- $\quad$ offering residents particularly polluted and highly urbanized region detailed plans for passive self-sufficient houses in terms of energy demand,

- granting low-interest (or interest-free) loans for the implementation of such projects.

\section{REFERENCES}

American Council for Energy Efficient Economy (2019a) 50-State Scorecard Reveals States Are Ramping Up Clean [Online]. Available at: https://www.aceee.org/press/2019/10/50-state-scorecard-reveals-states (Accessed: 10 April 2020).

American Council for Energy Efficient Economy (2019b) Energy Efficiency Resource Standards [Online]. Available at: https://database.aceee.org/state/energyefficiency-resource-standards (Accessed: 10 April 2020).

Asaff, B. Advantages and Disadvantages of Nuclear Energy [Online]. Available at: https://greenliving.lovetoknow.com/Advantages_and_Disadvantages_of_Nuclea r_Energy (Accessed: 10 April 2020).

Center for Climate and Energy Solutions (2019) Energy Efficiency Standards and Targets [Online]. Available at: https://www.c2es.org/document/energy-efficiencystandards-and-targets/ (Accessed: 10 April 2020).

Consumer Reports [Online]. Available at: www.consumerreport.org/solar-panels.howto-get-a-solar-tax-credit (Accessed: 03 May 2020).

Energy Efficiency Legislative (2019) National Conference of State Legislatures (NCSL) [Online]. Available at: https://www.ncsl.org/research/energy/energy-efficiencylegislative-update-2019.aspx (Accessed: 22 April 2020).

Energy Efficiency Resource Standards (EERS). National Conference of State Legislatures (NCSL) [Online]. Available at: https://www.ncsl.org/research/energy/energy-efficiency-resource-standardseers.aspx (Accessed: 10 April 2020).

Energy Information Administration (2020) What is US electricity generation by energy source? - FAQ - EIA [Online]. Available at: www.eia.gov (Accessed: 10 April 2020).

Energy Star. Available at: https://www.energystar.gov/index.cfm?useaction=HO (Accessed: 10 April 2020).

Federal Energy Regulatory Commission (2019) Annual Report of Major Electric Utilities, Licensees and Others [Online]. Available at: www.ferc.gov (Accessed: 10 April 2020).

Kamahina, R.S., Shamsuvaleeva, E.S. and Daibova, E.V. (2019) 'Green Certification to Achieve Sustainable Development Goals', Revista San Gregorio, Vol. 32, pp. $1-6$.

Kaufman, N. (2019) Clean Electricity Standard's Weaknesses May Be Its Biggest Strengths, Columbia / SIPA (Center on Global Energy Policy) [Online]. Available at: https://energypolicy.columbia.edu/research/commentary/clean-electricitystandards-weaknesses-may-be-its-biggest-strengths (Accessed: 10 April 2020).

Mazzola, E., Mora, T.D., Peron F. and Romagnoni P. (2019) 'An Integrated Energy and Environmental Audit Process for Historic Buildings', Energies, vol. 12, pp. 1-18.

Nadel, S. (2015) 35 Years of Energy Efficiency Progress, 35 More Year of Energy Efficiency Opportunity, American Council for an Energy-Efficient Economy [Online]. Available at: https://aceee.org/research-report/e1502 (Accessed: 10 April 2020).

Nocera, F., Giuffrida, A., Trovato, M.R. and Gagliano, A. (2019) 'Energy and New Economic Approach for Nearly Zero Energy Hotels', Entropy, Vol. 21, pp.1-15.

Office of Nuclear Energy (2020) Advantages and Challenges of Nuclear Energy [Online]. Available at: https://www.energy.gov/ne/articles/advantages-andchallenges-nuclear-energy (Accessed: 10 April 2020). 
The Outsider Club. Special Report: Investing in Coal: The Definitive SWOT Analysis [Online]. Available at: https://www.outsiderclub.com/report/investing-in-coal-thedefinitive-swot-analysis/1233 (Accessed: 10 April 2020).

Trabish, H.K. (2014) Utilities: What Are Renewables' Strengths, Weaknesses, Opportunities and Threats? [Online]. Available at: https://www.utilitydive.com/news/utilities-what-are-renewables-strengthsweaknesses-opportunities-and-th/261478/ (Accessed: 10 April 2020).

U.S. Energy Information Administration (2017) Construction Costs for Most Power Plant Types in Recent Years. Today in Energy, US Energy Information Administration. Available at: eia.gov/todayinenergy/detail.php?id=31912 (Accessed: 22 April 2020).

U.S. Energy Information Administration (2020), Coal explained. Use of coal [Online]. Available at: https://www.eia.gov/energyexplained/coal/use-of-coal.php (Accessed: 03 May 2020).

United States Environmental Protection Agency, Coal Ash Basics [Online]. Available at: https://www.epa.gov/coalash/coal-ash-basics (Accessed: 03 May 2020).

Von Knorring, H. (2019) 'Energy audits in shipping companies', Transportation Research Part A, Vol. 125, pp. 35-55.

Wang, T. (2019) Electricity and Use in the US 1975-2018 [Online]. Available at: https://www.statista.com/statistics/201794/us-electricity-consumption-since1975 (Accessed: 10 April 2020).

\begin{abstract}
.
The article includes a comparative analysis of different methods of solving energy problems especially meeting the demand for electricity. Energy problems became a global concern due to the rapid increase in the world population. Energy consumption reflects the habits of the society and the nature of the economy. The focus of the article is the analysis of the United States (USA) energy economy in terms of meeting the needs of industry and society. It includes a comparison of costs of generating electricity obtained from various sources. It also includes an analysis of opportunities and threats related to the energy sector's dependence on individual energy sources. Meeting the demand for electricity cannot be solved by increasing only the energy generation. The cost of increasing electricity production is always higher compared to increasing energy efficiency. The impact of energy efficiency of devices on energy management was also assessed. The publication also contains practical conclusions and recommendations regarding energy management on a global scale.
\end{abstract}

Keywords: Energy consumption, Energy economy, energy fuels, power plants, renewable energy 